\title{
2. MAJOR AND TRACE ELEMENT VARIATIONS IN BASALTS FROM LEG 115 ${ }^{1}$
}

\author{
Alistair N. Baxter ${ }^{2}$
}

\begin{abstract}
Basalts recovered from Sites 706 (34 Ma), 707 (64 Ma), 713 (49 Ma), and 715 (57 Ma) along the Deccan-Réunion hotspot lineament are all tholeiitic, with differentiation indexes varying from 16 to 31 and magnesium ratios from 31 to 64 . They are predominantly porphyritic, with phenocryst assemblages at Sites 706,707 , and 713 dominated by plagioclase, with subordinate augite and minor olivine. Site 715 lavas, which include the most mafic varieties found on Leg 115 , are almost exclusively olivine-phyric.

In terms of compatible major and trace elements, Sites 706, 707, and 713 comprise mildly differentiated suites with variation controlled by limited shallow-level fractionation of plagioclase + augite \pm olivine. Incompatible-element abundances and ratios suggest, however, that two separate magma types with variably developed Mid-Ocean Ridge basalt (MORB) and oceanic-island basalt (OIB) characteristics may be present at these sites. Site 715 basalts, in contrast, show OIB affinities, approximating the Réunion compositions.

Average incompatible-element ratios $\left(\mathrm{Ba} / \mathrm{TiO}_{2}, \mathrm{NB} / \mathrm{Y}\right.$, and $\left.\mathrm{Zr} / \mathrm{Nb}\right)$ for all components of the hotspot trace reveal the presence of an overall linear change with decreasing age from MORB- to OIB-type values, although significant local deviations from the trend occur. The association of MORB-dominated site chemistry with periods when the hotspot was adjacent to spreading ridges could indicate that the tectonic setting of hotspot magmatism was a major determinant in controlling the extent of plume/asthenospheric source mixing. However, there is evidence that the Réunion hotspot initially was a highly productive thermal event that is now waning. In this case, compositional variations along this lineament may have resulted from substantial asthenospheric entrainment in the early, ascending mantle plume, which declined with time to yield OIB-dominated compositions.
\end{abstract}

\section{INTRODUCTION}

The Réunion hotspot has been active for at least 67 m.y. (Duncan and Pyle, 1988), bounded by the well-described volcanism of the Deccan Traps (Mahoney, 1988; Cox and Hawkesworth, 1984) in the north and by the volcanic islands of Réunion (0-2 Ma; McDougall, 1971) and Mauritius (7-8 Ma; McDougall and Chamalaun, 1969) in the south (Upton and Wadsworth, 1972; Baxter, 1975, 1976). A formerly continuous submarine volcanic ridge, split in the last $34 \mathrm{~m} . \mathrm{y}$. by spreading along the Central Indian Ridge (CIR), links these subaerial expressions of hotspot activity. The volcanic trail becomes younger from the western Deccan Traps through the Laccadive, Maldive, and Chagos islands and along the Mascarene Plateau from the Saya de Malha Bank to the Cargados Carajos shoals (Fig. 1). Deep basins and the Rodrigues Ridge separate the lineament from the independent shield edifices of Mauritius and Réunion, implying that hotspot productivity was waning by the late Miocene with the formation of islands rather than coalesced lineaments.

The ridge crest is capped by shallow-water reef and other carbonate sediments up to $2.4 \mathrm{~km}$ thick (Meyerhoff and $\mathrm{Ka}$ men-Kaye, 1981), and its flanks are draped with nannofossil oozes and chalks. Industry drilling at two sites on the crest of the Mascarene Plateau (Saya de Malha and Nazareth banks) penetrated several hundred meters into the volcanic basement recovering altered basalts and subordinate tuffs.

\section{ANALYTICAL METHODOLOGY}

All analytical work was carried out using an Applied Research Laboratories 8420 wavelength-dispersive X-ray fluores-

\footnotetext{
${ }^{1}$ Duncan, R. A., Backman, J., Peterson, L. C., et al., 1990. Proc. ODP, Sci. Results, 115: College Station, TX (Ocean Drilling Program).

2 School of Earth Sciences, Thames Polytechnic, London E1 2NG, United Kingdom.
}

cence (XRF) spectrometer equipped with a 3-kw rhodium tube. Approximately $10 \mathrm{~cm}^{3}$ of rock sample was crushed in a PTFElined hydraulic press and then ground in a tungsten carbide (cobalt carbide-bonded) swingmill. Major element measurements were determined on fused glass discs made from $6 \mathrm{~g}$ of lanthanum-doped lithium metaborate flux mixed with $0.5 \mathrm{~g}$ of sample and heated to $1030^{\circ} \mathrm{C}$ for about $10 \mathrm{~min}$. Trace element values were determined on pressed powder tablets made from $5 \mathrm{~g}$ of sample, with a polyvinyl alcohol binder.

We used 15 well-documented international standards for calibration. On-line corrections were made for drift, background, spectral interference, and mass absorbance. Details of the routine precision obtained for both major and trace elements are presented in Table 1.

\section{INTRASITE GEOCHEMISTRY}

\section{Hole $706 \mathrm{C}$}

Thirty-two lava units were recognized in the recovered core according to lithologic and textural criteria (Backman, Duncan, et al., 1988). The entire suite was erupted in submarine conditions and comprises a sequence of pillow lavas. The flows are all vesicular, microporphyritic to porphyritic basalts, with plagioclase $($ average $=15$ modal $\%$ ), augite $($ average $=7 \%$ ), and olivine (average $=2 \%$ ) phenocryst $/$ microphenocryst assemblages set in a glass-dominated groundmass. The units are mineralogically similar, but the lowest units (31-32) are distinguished by the presence of abundant plagioclase phenocrysts, compared with the dominantly microphyric character of the upper units (1-30).

Normative compositions for the upper units (calculated with $\left.\mathrm{FeO} /\left(\mathrm{FeO}+\mathrm{Fe}_{2} \mathrm{O}_{3}\right)=0.15\right)$ show them to be tholeiites with $10 \%-24 \%$ hypersthene and variously $0 \%-2 \%$ quartz or $0 \%-$ $4 \%$ olivine. Units 31 and 32 are olivine tholeiites, with $11 \%$ $13 \%$ hypersthene and $2 \%-3 \%$ olivine. Differentiation indexes (DI) for the upper units range from 24 to 31 and in the lower units from 19 to 21 . 


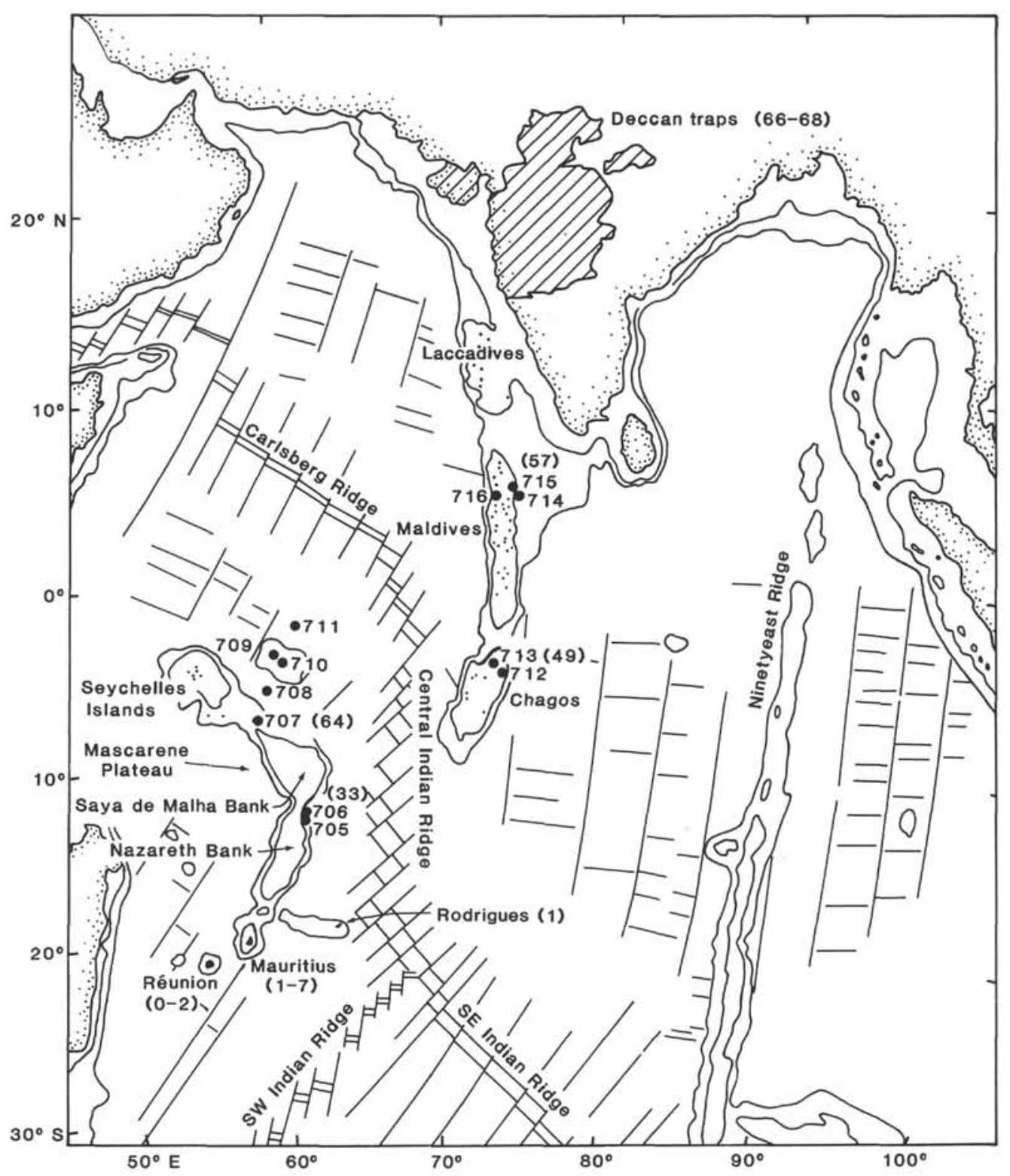

Figure 1. Bathymetric map of the western and central Indian Ocean showing major tectonic features, the Deccan-Réunion hotspot track, and sites drilled on Leg 115. Ages of basalts (Ma) are given in parentheses.

Magnesium ratios $\left(100 \mathrm{Mg} / \mathrm{Mg}+\mathrm{Fe}^{2}\right)$ from the upper units range from 31 to 42 , which in conjunction with the variation in DI values, indicates they are mildly differentiated. Lower unit ratios are higher, at 49 to 54 , reflecting their significantly lower $\mathrm{FeO}$ content at equivalent $\mathrm{MgO}$ levels:

All 31 analyses for Site $706 \mathrm{C}$ basalts are presented in Backman, Duncan, et al. (1988). MgO variation diagrams (Fig. 2) show that the upper and lower flow units are chemically distinct, the latter characterized by high $\mathrm{Al}_{2} \mathrm{O}_{3}$ and $\mathrm{CaO}$ and low total iron. The lower units are also depleted in $\mathrm{TiO}_{2}, \mathrm{~K}_{2} \mathrm{O}, \mathrm{P}_{2} \mathrm{O}_{5}$, and the incompatible trace elements $\mathrm{Ba}, \mathrm{Sr}, \mathrm{Zr}, \mathrm{Nb}, \mathrm{Ca}$, and $\mathrm{Y}$. Low $\mathrm{MnO}$ and $\mathrm{V}$ levels in the lower group are consistent with the low iron and $\mathrm{TiO}_{2}$ abundances, for which these trace elements respectively substitute in mineral lattices.

The upper units show weakly defined trends over their $\mathrm{MgO}$ range of $4 \%-6 \%$ for $\mathrm{Al}_{2} \mathrm{O}_{3}, \mathrm{TiO}_{2}$, total iron, $\mathrm{Ni}, \mathrm{Cr}, \mathrm{V}, \mathrm{Zr}, \mathrm{Nb}$, $\mathrm{Ce}$, and $\mathrm{Zn}$. These patterns are consistent with modest fractionation of plagioclase + augite + olivine (i.e., the observed mi- crophenocryst phases). The scattered patterns for $\mathrm{Na}_{2} \mathrm{O}$ and the large-ion-lithophile elements (LIL) $\mathrm{K}_{2} \mathrm{O}, \mathrm{Rb}, \mathrm{Ba}$, and $\mathrm{Sr}$ probably result in part from alteration processes, such as basalt-seawater interaction.

The upper units, with their strongly tholeiitic character, relatively high $\mathrm{TiO}_{2}, \mathrm{Fe}$, and alkalis, and elevated incompatible trace element levels, show oceanic-island basalt (OIB) affinities. Of the adjacent Mascarene Islands, they are most similar to the less magnesian basalts from the shield series lavas of Réunion (cf. Upton and Wadsworth, 1972; Fisk et al., 1988). In comparison, the lower units with their depleted incompatible-element chemistry, high $\mathrm{Al}_{2} \mathrm{O}_{3}$ and $\mathrm{CaO}$, and relatively low total iron, approach MORB compositions, for example, material dredged from the CIR (cf. Humler and Whitechurch, 1988; Mahoney et al., 1989).

Incompatible-element ratio plots can be used to characterize and discriminate mantle source compositions, as these ratios are normally insensitive to such crystal-liquid equilibria processes 
Table 1. X-ray fluorescence precision data, Leg 115.

\begin{tabular}{|c|c|c|c|}
\hline Oxide & $\begin{array}{c}\text { Mean } \\
(N=15) \\
(\mathrm{Wt} \%)\end{array}$ & $\begin{array}{l}\text { SD } \\
\text { (1) }\end{array}$ & $\begin{array}{l}\text { RD } \\
(\%)\end{array}$ \\
\hline \multicolumn{4}{|c|}{ BHVO-1 (Anhydrous) Hawaiian tholeiite: } \\
\hline $\mathrm{SiO}_{2}$ & 49.79 & 0.10 & 0.20 \\
\hline $\mathrm{TiO}_{2}$ & 2.74 & 0.01 & 0.36 \\
\hline $\mathrm{Al}_{2} \mathrm{O}_{3}$ & 13.60 & 0.04 & 0.30 \\
\hline $\mathrm{Fe}_{2} \mathrm{O}_{3}$ & 12.28 & 0.04 & 0.34 \\
\hline $\mathrm{MnO}$ & 0.17 & 0.01 & \\
\hline $\mathrm{MgO}$ & 7.08 & 0.04 & 0.54 \\
\hline $\mathrm{CaO}$ & 11.51 & 0.02 & 0.54 \\
\hline $\mathrm{Na}_{2} \mathrm{OL}$ & 2.44 & 0.07 & 2.80 \\
\hline $\mathrm{K}_{2} \mathrm{O}$ & 0.55 & 0.01 & \\
\hline $\mathrm{P}_{2} \mathrm{O}_{5}$ & 0.26 & $<0.01$ & \\
\hline Element & $\begin{array}{c}\text { Mean } \\
(N=9) \\
(\mathrm{ppm})\end{array}$ & $\begin{array}{l}\text { SD } \\
\text { (1) }\end{array}$ & $\begin{array}{l}\text { RD } \\
(\%)\end{array}$ \\
\hline \multicolumn{4}{|c|}{ AII 92-29-1 Mid-Atlantic Ridge basalt } \\
\hline $\mathrm{Nb}$ & 4.3 & 0.37 & 8.6 \\
\hline $\mathrm{Zr}$ & 129.9 & 0.73 & 0.5 \\
\hline $\mathrm{Y}$ & 40.6 & 0.30 & 0.75 \\
\hline $\mathrm{Sr}$ & 129.1 & 0.96 & 0.74 \\
\hline $\mathrm{Rb}$ & 1.3 & 0.35 & \\
\hline $\mathrm{Zn}$ & 85.4 & 0.83 & 0.98 \\
\hline $\mathrm{Cu}$ & 63.3 & 1.20 & 1.8 \\
\hline $\mathrm{Ni}$ & 102.6 & 1.20 & 1.14 \\
\hline $\mathrm{Cr}$ & 238 & 6.8 & 2.8 \\
\hline V & 292 & 5.7 & 1.9 \\
\hline $\mathrm{Ce}$ & 8.3 & 2.4 & \\
\hline $\mathrm{Ba}$ & 18.4 & 7.8 & \\
\hline
\end{tabular}

Notes: BHVO-1 $=$ U.S. Geological Survey basalt standard; AII 92-29-1 = MORB standard supplied by W. B. Byran. SD $=$ standard deviation, $\mathrm{RD}=$ real deviation, and $\mathrm{ppm}=$ parts per million.

as large-scale partial melting or fractionation (Allégre et al., 1977; Pearce and Norry, 1979). Within the incompatible group, however, the LIL elements (e.g., K, Rb, etc.) are potentially more mobile than the high-field-strength (HFS) elements (e.g., $\mathrm{Ti}, \mathrm{P}, \mathrm{Zr}, \mathrm{Y}$, etc.) and can be significantly modified by assimilative or weathering processes (see, e.g., Wood et al., 1979; Clague and Frey, 1982).

Table 2 lists some of these ratios for Sites 706, 707, 713, and 715 as well as averages for central Indian Ocean MORB, Réunion and Mauritius, and the Deccan formations. Clear differences exist between the upper- and lower-group lavas of Site 706 , the latter having lower $\mathrm{Zr} / \mathrm{Y}, \mathrm{Nb} / \mathrm{Y}, \mathrm{Zr} / \mathrm{Nb}$, and $\mathrm{Ba} / \mathrm{Y} \mathrm{ra}-$ tios and higher $\mathrm{Ti} / \mathrm{Zr}$ and $\mathrm{Ba} / \mathrm{TiO}_{2}$ ratios. Incompatible-element abundances in the lower group approach central Indian Ocean MORB values, but their ratios are substantially different, implying quite different source characteristics. Interestingly, ratios for the lower group show much closer affinities to the Ambenali Formation of the Deccan Traps, which are recognized as essentially uncontaminated basalts with a mantle source slightly enriched relative to MORB (Cox and Hawkesworth, 1985). However, the absolute incompatible-element abundances for the lower-group lavas are significantly lower than those for the Ambenali Formation, at equivalent $\mathrm{MgO}$ levels, implying an even more depleted source for them.

The OIB-type affinities of the upper-group lavas are confirmed by their incompatible-element ratios. They approach the values for Réunion, although a source significantly more depleted in barium is implied by the substantially lower $\mathrm{Ba} / \mathrm{Y}$ and $\mathrm{Ba} / \mathrm{TiO}_{2}$ ratios of the Site 706 basalts.
The contrasting characteristics of the upper and lower lava groups at Site 706 may be reconcilable when viewed in the context of the tectonic setting of magmatism. Plate reconstructions for their time of formation ( $34 \mathrm{Ma}$; Duncan, this volume) place the Réunion hotspot under the nascent CIR, with eruption on essentially zero-age crust. In such a setting, Site 706 is well placed to tap OIB-type (plume), MORB-like (asthenospheric), or mixtures of these sources, as the plume material rose through the MORB source region. If large-scale upwelling of plume mantle led to its local dominance in the high melting regime underlying ridge crests, then the partial melting contrasts alone between this and deeper small-scale plume melts could generate significant chemical diversity.

The enriched upper-group lavas could represent a period during which OIB-type source melting was dominant. The low $\mathrm{Ba}$ levels relative to Réunion may indicate a less enriched source or, alternatively, could reflect mixing with MORB-like mantle. In this model, the lower-group lavas would represent a phase of dominance of asthenospheric melting, although the significant differences in their incompatible-element ratios compared with CIR-type MORB implies that the melting region incorporated plume-type material.

Alternative solutions for the compositional variations seen at Site 706 do not readily fit the data. Given the similarity of the $\mathrm{MgO}$ levels in the upper and lower groups and the relative incompatible-element enrichment of the former (by a factor of 24 ), differentiation of the two groups by simple crystal fractionation can be ruled out.

\section{Hole 707C}

Five basalt units were identified at Hole $707 \mathrm{C}$, which are dated at $64 \mathrm{Ma}$ on the basis of biostratigraphic evidence (Backman, Duncan, et al., 1988) and radiometric dating (Duncan and Hargraves, this volume). Textural and lithologic data (Backman, Duncan, et al., 1988) show these to be subaerially erupted, often thick porphyritic flows that are dominated by plagioclase phenocrysts (5-22 modal \%) and that contain subordinate augite $(1 \%-15 \%)$ and olivine $(0 \%-3 \%)$. Plate reconstructions for this period place Site 707 within the geographic province of the western Deccan Traps, although activity was slightly later than the main phase of continental volcanism (Duncan and Pyle, 1988). Structurally and petrographically, Site 707 basalts can be tentatively correlated with the lower part of the Ambenali Formation of the Deccan sequence, which concurs with the similarity of their incompatible-element ratios (Fisk et al., 1989).

Hole $707 \mathrm{C}$ basalts, like those of Hole $706 \mathrm{C}$, are tholeiitic (20\%-30\% hypersthene, $0 \%-2 \%$ quartz, or $0 \%-7 \%$ olivine). Differentiation indexes range from 16 to 21 , and magnesium ratios from 45 to 60 , reflecting the significantly more mafic, $\mathrm{MgO}$ rich character of these lavas.

Fifteen samples were analyzed from the five units (compositions reported in Backman, Duncan, et al., 1988). The MgO plots for these are presented in Figure 2. The data reveal a complex history of magmatism at this site. The incompatible major elements $\mathrm{TiO}_{2}$ and $\mathrm{P}_{2} \mathrm{O}_{5}$, together with the trace elements $\mathrm{Ba}$, $\mathrm{Sr}, \mathrm{Zr}, \mathrm{Nb}, \mathrm{Ce}$, and $\mathrm{Y}$, show that two distinct magma types are present, with quite different enrichment levels. Units 4 and 5 are moderately enriched with, for example, $1.4 \%-1.5 \% \mathrm{TiO}_{2}, 0.10 \%$ $\mathrm{P}_{2} \mathrm{O}_{5}, 80-85 \mathrm{ppm} \mathrm{Zr}$, and 5-7 ppm Nb. In contrast, Units 1-3 are depleted, showing levels of $0.5 \%-0.8 \% \mathrm{TiO}_{2}, 0.02 \%-0.03 \%$ $\mathrm{P}_{2} \mathrm{O}_{5}, 20-35 \mathrm{ppm} \mathrm{Zr}$, and $1.5-2.5 \mathrm{ppm} \mathrm{Nb}$.

Overall, the lower lava group are one to four times more enriched in incompatible elements than the upper group, but with La showing an exceptional enrichment of seventy times. The enrichment is associated with lower $\mathrm{MgO}(7 \% \mathrm{cf}$. $8 \%-11 \%)$ and higher $\mathrm{FeO}(8 \%-9 \%$ cf. $10 \%-11 \%)$. The enriched group are also generally less siliceous and aluminous (see Fig. 2). These 

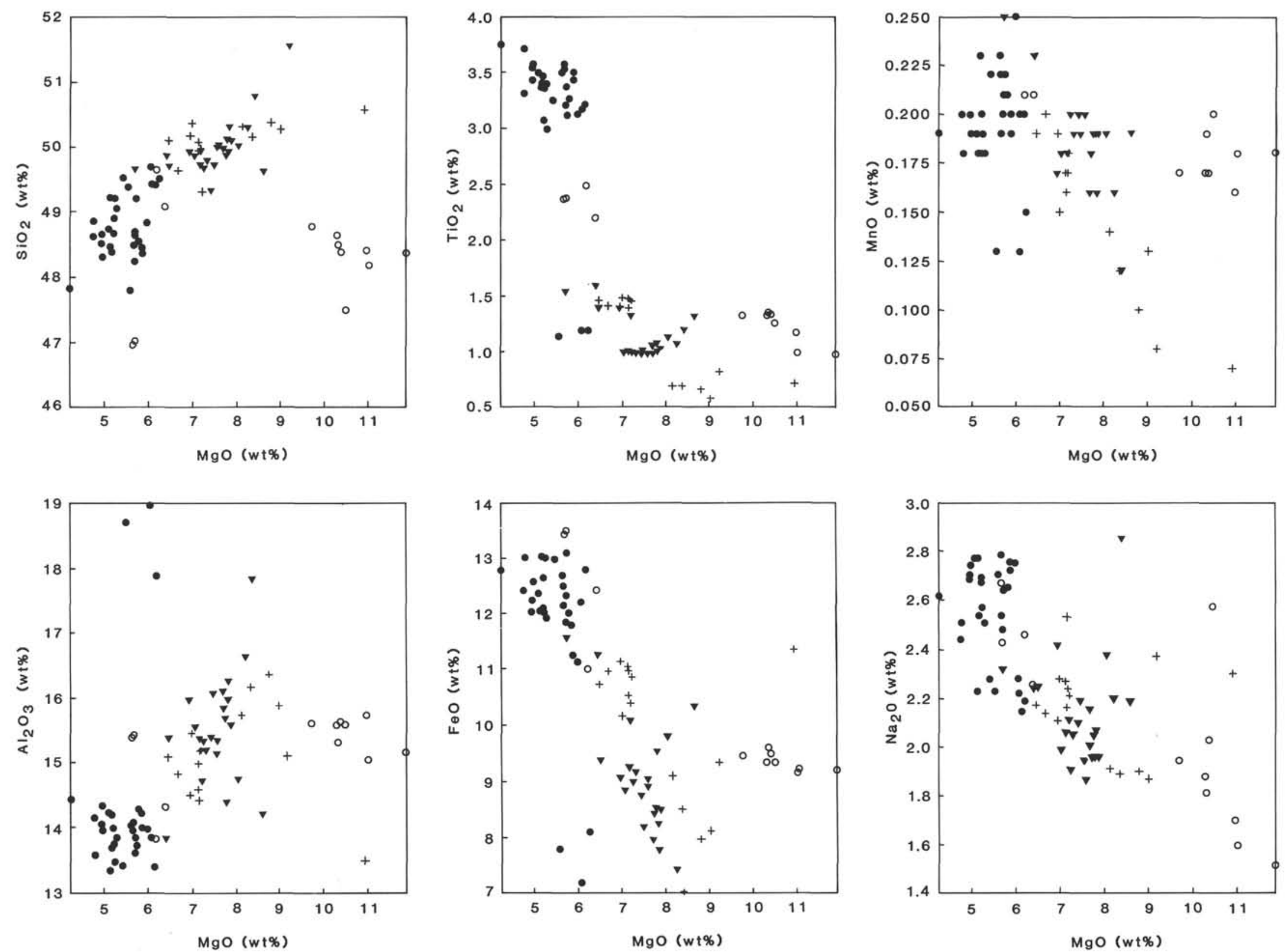

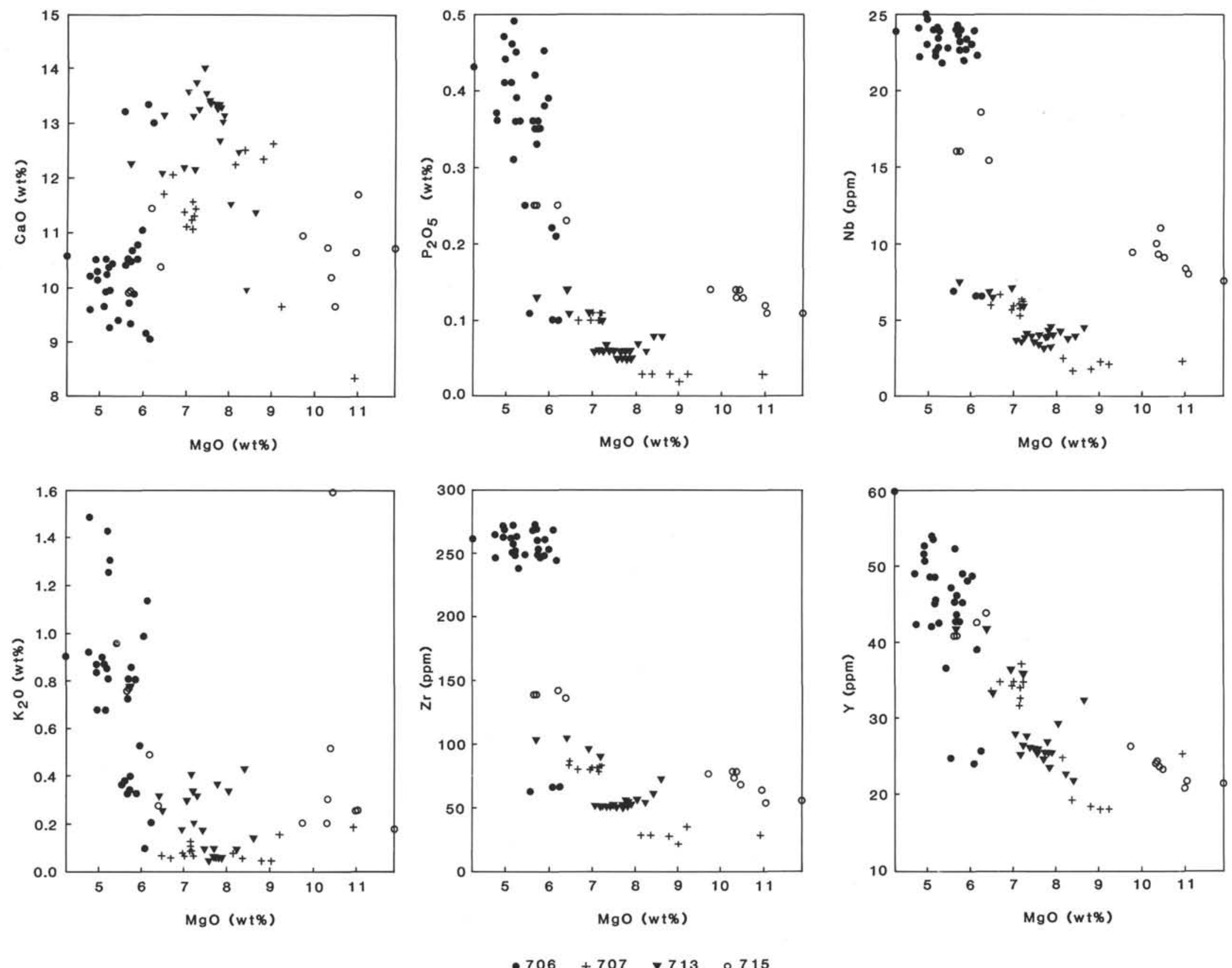

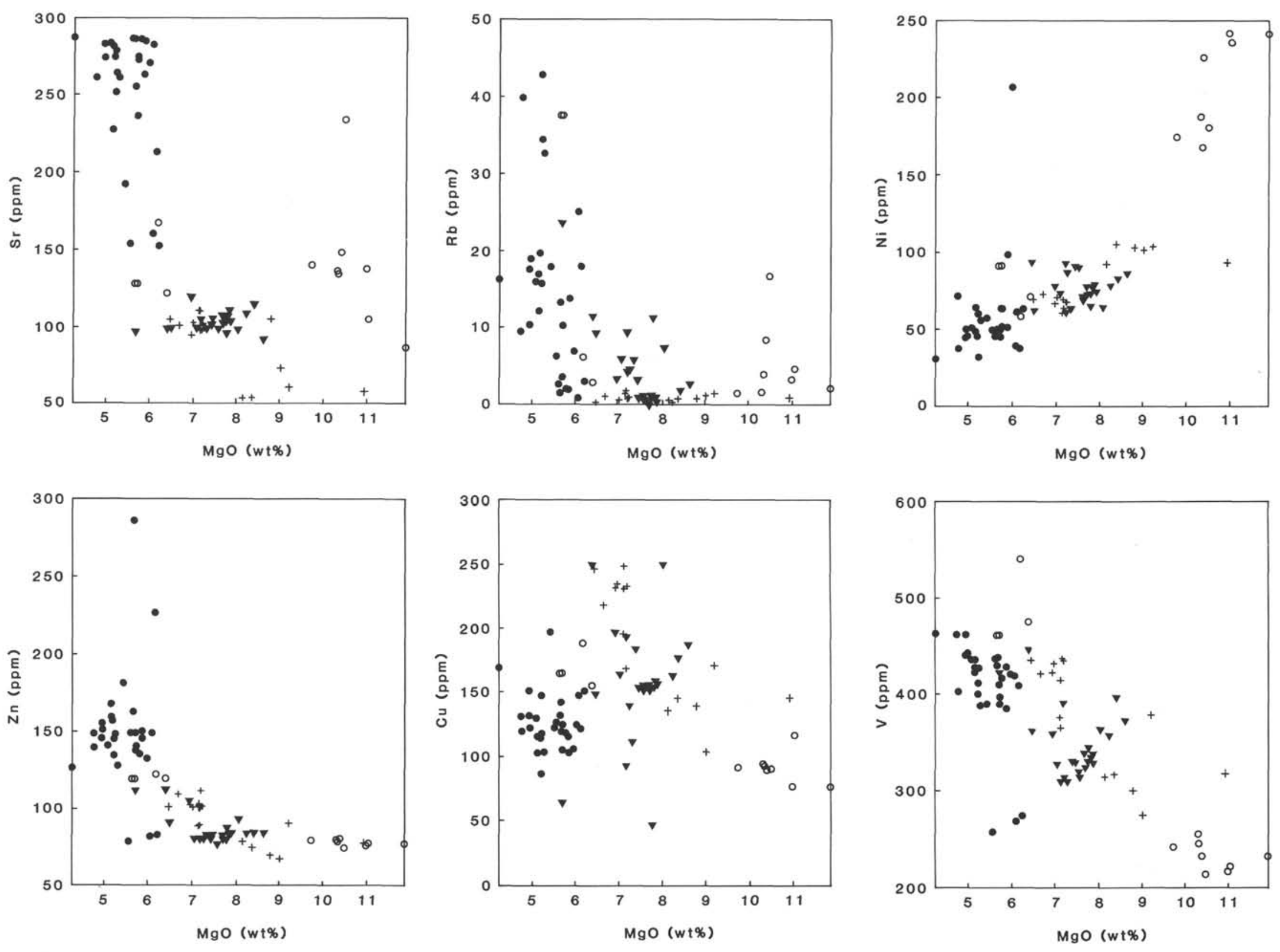

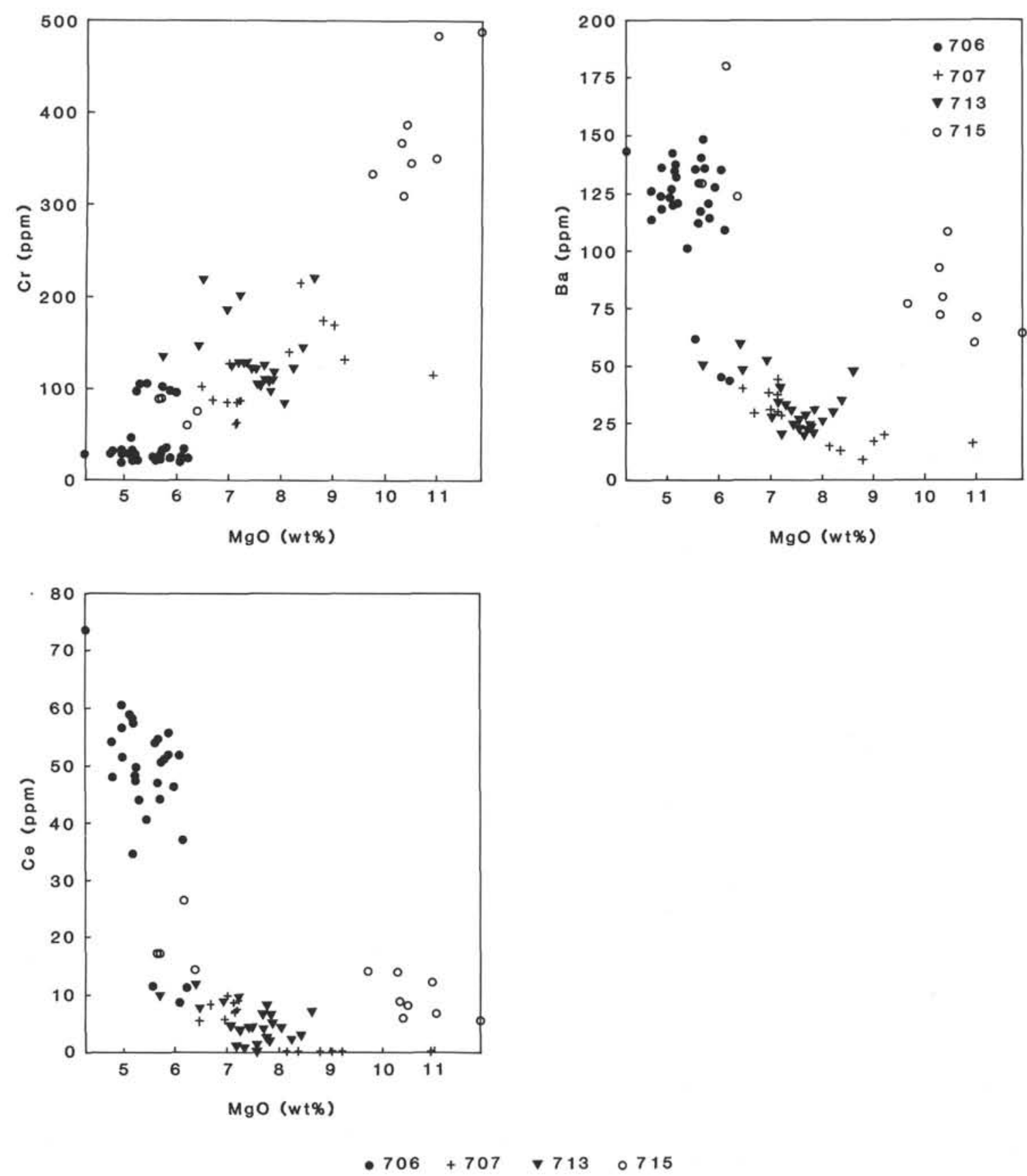
Table 2. Average incompatible element ratios for Sites 706, 707, and 713 upper and lower group lavas, Site $\mathbf{7 1 5}$ low and high $\mathbf{M g O}$ classes, central Indian Ocean MORB, Réunion, Mauritius, and the Deccan formations.

\begin{tabular}{lllrccc}
\hline \multicolumn{1}{c}{ Lava group } & $\mathrm{Zr} / \mathrm{Y}$ & $\mathrm{Ba} / \mathrm{Y}$ & $\mathrm{Ti} / \mathrm{Zr}$ & $\mathrm{Ba} / \mathrm{TiO}_{2}$ & $\mathrm{Nb} / \mathrm{Y}$ & $\mathrm{Zr} / \mathrm{Nb}$ \\
\hline 706 upper & 5.5 & 2.7 & 78 & 38 & 0.50 & 11 \\
706 lower & 2.6 & 1.9 & 109 & 42 & 0.26 & 9.7 \\
707 upper & 1.42 & 0.72 & 145 & 21 & 0.10 & 12 \\
707 lower & 2.39 & 0.99 & 106 & 23 & 0.18 & 14 \\
713 upper & 2.50 & 1.35 & 92 & 35 & 0.17 & 14 \\
713 lower & 2.10 & 1.03 & 115 & 26 & 0.15 & 14 \\
715 low MgO class & 3.3 & 3.4 & 100 & 62 & 0.39 & 8.3 \\
715 high MgO class & 3.0 & 3.4 & 105 & 64 & 0.40 & 7.5 \\
MORB & 3 & 0.5 & 80 & 20 & 0.06 & 50 \\
Réunion & 6 & 5.6 & 82 & 70 & 0.87 & 7.5 \\
Mauritius & 5 & 8 & 84 & 95 & 0.65 & 7.4 \\
Deccan: & & & & & & \\
$\quad$ Poladpur & 4.0 & 3.9 & 85 & 69 & 0.28 & 14 \\
$\quad$ Ambenali & 3.8 & 2.0 & 101 & 32 & 0.29 & 12 \\
$\quad$ Mahabaleshwar & 4.5 & 4.3 & 95 & 59 & 0.49 & 9.3 \\
\hline
\end{tabular}

Notes: Sources of data are as follows; Sites $706,707,713$, and 715 are from Backman, Duncan, et al. (1988); MORB data from Mahoney et al. (1989); Réunion data from Upton and Wadsworth (1972) and Fisk et al. (1989); Deccan, from Cox and Hawkesworth (1985); and Mauritius, from Baxter (1972).

minor variations in the compatible major elements may, in part, reflect modest differential degrees of plagioclase-dominated fractionation (consistent with the observed phenocryst phase proportions). This could not, however, account for the much greater enrichment factors seen in the incompatible elements. For example, Rayleigh modeling for $\mathrm{Zr}, \mathrm{Nb}$, and $\mathrm{Y}$ requires $50 \%-70 \%$ fractionation to generate the observed variation across the interval from $8.5 \%$ to $7 \% \mathrm{MgO}$.

In terms of incompatible-element abundances, the uppergroup lavas show more depleted, MORB-like characteristics than those seen in the lower units at Hole 706C. This is further borne out by inspection of incompatible-element ratios (Table 2). For example, $\mathrm{Ba} / \mathrm{TiO}_{2}$ and $\mathrm{Nb} / \mathrm{Y}$ values average 21 and 0.06 , respectively, close to values for Indian Ocean MORB (20 and 0.10 ), implying a similarly depleted source. $\mathrm{The} \mathrm{Zr} / \mathrm{Nb}$ value (13) is, however, strikingly different from the average MORB value of 50 .

The enriched lower-group lavas from Site 707, although chemically similar in some respects to those from the Ambenali Formation of the Deccan Traps, are significantly depleted in incompatible elements for similar $\mathrm{MgO}$ values (cf. Cox and Hawksworth, 1984, 1985). For example, at about $6.5 \% \mathrm{MgO}$, average values for $\mathrm{Ba}$ are 32 (cf. $71 \mathrm{ppm}$ ); Sr, 105 (cf. $217 \mathrm{ppm}$ ); Zr, 81 (cf. 133 ppm); $\mathrm{Nb}, 6$ (cf. 10); and $\mathrm{TiO}_{2}, 1.43$ (cf. 2.24). Incompatible-element ratios (Table 2) emphasize these differences, showing significantly lower values for $\mathrm{Zr} / \mathrm{Y}, \mathrm{Ba} / \mathrm{TiO}_{2}$, and $\mathrm{Nb}$ / $\mathrm{Y}$ ratios in the lower-group lavas relative to the Ambenali Formation or, indeed, to any of the Deccan formations.

Site 707 basalts were erupted subaerially on the western margin of the Deccan province, probably as rifting began on the Carlsberg Ridge (Fisk et al., 1989). The occurrence of MORBlike and continent-type tholeiites is, therefore, not surprising, as both asthenospheric (MORB) and plume mantle sources were likely to be available. The logical interpretation of the geochemical data for Site 707 is that, although the upper-group lavas resulted from a phase of melting of dominantly asthenospheric mantle, the more enriched lower group represents a period when plume-type and asthenospheric sources were involved, producing a trace element signature reflecting this hybrid source.

\section{Hole 713A}

Sediments immediately overlying and intercalated with the volcanic basement are dated at $49 \mathrm{Ma}$ (Duncan and Hargraves, this volume). Recovered material is a typically vesicular, microphyric-porphyritic, fine-grained basalt that was erupted in a submarine environment. A total of 35 lava units were recognized on lithologic, textural, and petrographic grounds (Backman, Duncan, et al., 1988). Phenocryst/microphenocryst assemblages are dominated by plagioclase $\left(\mathrm{An}_{50-65}, 1-30\right.$ modal $\%$ ), augite $(1 \%-40 \%)$, olivine $(0 \%-2 \%)$, and Fe-Ti oxides $(0 \%$ $5 \%$ ) set in a glassy groundmass.

Normative compositions for all 24 basalts analyzed show them to be olivine tholeiites, with $7 \%-19 \%$ hypersthene and $0 \%-7 \%$ olivine. Differentiation indexes range from 16 to 27 , and magnesium ratios from 40 to 62 . Major and trace element data for these lavas were presented in Backman, Duncan, et al. (1988), and $\mathrm{MgO}$ plots are shown in Figure 2.

Plate reconstructions for Site 707 activity place it in an intraplate, oceanic environment but close to a long north-northeast-trending transform fault that linked the Carlsberg Ridge with pre-CIR spreading in the central Indian Ocean (Schlich, 1982; Duncan, this volume). This near-plate boundary setting is significant when viewed in relation to the basalt geochemistry of the site, which is dominated by depleted, MORB-like compositions. Taken overall, the lavas represent a modestly differentiated suite, with $\mathrm{MgO}$ varying from about $5.70 \%$ to $8.60 \%$.

$\mathrm{The} \mathrm{MgO}$ plots for these elements illustrate broad trends that are consistent with fractionation of plagioclase + minor augite. As seen at Sites 706 and 707, incompatible-element abundances indicate that two contrasting magma types are present, although the distinction between these is less clear cut here, probably because of the overprinting effects of high-level crystal fractionation. These consist of a small upper group (Units 1-5) of slightly enriched basalts very similar to the lower-group lavas of Site 707 and a much larger group (Units 6-35) of significantly more depleted basalts with incompatible-element abundances intermediate to those of the MORB-like lavas seen at Sites 706 and 707.

Overall, at Site 713 the upper-group lavas show enrichment factors of 1.5-2.0 when compared with incompatible-element abundances in the lower group. As at Site 707, enrichment is associated with lower $\mathrm{MgO}$ levels in the upper-group lavas (average about $6.5 \%$; cf. $7.8 \%$ ). Although marginally more evolved than the lower group, the enrichment factors seen in the upper group are too large to be attributable to simple fractionation of plagioclase + clinopyroxene alone. Rayleigh modeling for $\mathrm{Ba}$, $\mathrm{Zr}$, and $\mathrm{Nb}$ requires around $45 \%-60 \%$ crystallization to generate the observed enrichment trends for these elements over the range $8 \%-6 \% \mathrm{MgO}$. This result is inconsistent with the modest amounts of crystallization required to generate the observed major element variation over this $\mathrm{MgO}$ interval. This observation, however, is relevant only for closed-system fractionation; opensystem behavior could potentially allow much greater enrichment for small changes in major element chemistry.

Incompatible-element ratios (Table 2) generally confirm the presence of two magma types at Site 713. The lower, depleted lava group is characterized by significantly lower $\mathrm{Zr} / \mathrm{Y}, \mathrm{Ba} / \mathrm{Y}$, and $\mathrm{Ba} / \mathrm{TiO}_{2}$ ratios than the upper group. These ratios are essentially intermediate between those of the depleted lava groups from Sites 706 and 707. In contrast, the enriched upper-group lavas display few source affinities with Site 707 in terms of these ratios.

As at Sites 706 and 707, the implications of the geochemical data are of a temporal interplay of plume-type and asthenospheric mantle processes, with the sources for both lava groups being hybrid and respectively weighted toward more MORBand OIB-like characteristics in this case.

\section{Hole 715A}

The upper part of the volcanic basement at this site is dated at $57 \mathrm{Ma}$ (Backman, Duncan, et al., 1988). Activity at Site 715 
was entirely subaerial, on the basis of recovered core material that consisted of variably laterized flows (0.07-5.41 m thick) of porphyritic, mildly vesicular basalt. Eighteen lava units were recognized on lithologic and petrographic criteria (Backman, Duncan, et al., 1988), which can be grouped, in turn, into two compositional types (Units 2, 4, 5, and 7, and Units 9-12). The upper group consists of sparsely porphyritic (1\%-5\%) flows with phenocrysts of plagioclase (maximum $3 \%$ ) + augite $(0 \%$ $1 \%)+$ olivine $(0 \%-1 \%)$. In contrast, the lower-group basalts appear petrographically more mafic with olivine (maximum 15 modal \%) as the sole phenocryst phase, except in Unit 12 where it is accompanied by plagioclase $\left(\mathrm{An}_{60}=20 \%\right)$ and augite $(1 \%)$.

Eleven samples were analyzed from Site 715 , which came entirely from the lower group. Alteration in the upper-group lavas precluded their analysis. Major and trace element data for these were presented in Backman, Duncan, et al. (1988), and the $\mathrm{MgO}$ plots are given in Figure 2. Normative compositions show the basalts to be predominantly olivine tholeiites, with $0 \%-23 \%$ olivine and $0 \%-25 \%$ hypersthene. Differentiation indexes range from 16 to 28 , and magnesium ratios from 37 to 64 . These parameters collectively show the fairly differentiated nature of basalts from Site 715 , which include the most mafic, olivine-rich lavas recovered on Leg 115.

The $\mathrm{MgO}$ plots show reasonably coherent patterns of olivine control in keeping with the predominance of olivine as a phenocryst phase. Levels of $\mathrm{MgO}$ range from $5.6 \%$ to $11.8 \%$, with a compositional gap from about $6.5 \%$ to $9.7 \%$. The major elements $\mathrm{SiO}_{2}, \mathrm{CaO}$, and $\mathrm{K}_{2} \mathrm{O}$, and the trace elements $\mathrm{Rb}, \mathrm{Sr}$, and $\mathrm{Ce}$ all show variably dispersed patterns on $\mathrm{MgO}$ plots. This may reflect, in part, element mobilization in these altered, subaerially weathered lavas. In contrast, however, $\mathrm{FeO}, \mathrm{TiO}_{2}, \mathrm{Na}_{2} \mathrm{O}, \mathrm{P}_{2} \mathrm{O} 5$, $\mathrm{Ni}, \mathrm{Cr}$, and the other trace elements all show more systematic behavior. On the basis of these elements, the lavas comprise two compositionally separate classes: one with low $\mathrm{MgO}, \mathrm{Ni}$, and $\mathrm{Cr}$ but with higher levels of the other elements; and another group with high $\mathrm{MgO}, \mathrm{Ni}$, and $\mathrm{Cr}$ but significantly depleted levels of the other elements.

Despite the compositional gap between the two classes, $\mathrm{MgO}$ plots for these elements show them to lie on common linear trends, implying control by crystal fractionation. In general, the trends are consistent with olivine + plagioclase removal. Rayleigh modeling for $\mathrm{Ba}, \mathrm{Sr}, \mathrm{Zr}$, and $\mathrm{Nb}$ requires around $40 \%$ crystallization to generate the observed trends over the interval from $10 \%$ to $6 \% \mathrm{MgO}$, which is consistent with the results for major element modeling.

The differentiated Site 715 lavas more closely resemble Mauritius and Réunion basalts than the rather uniform Deccan lava formations. However, Site 715 basalts are significantly more depleted in incompatible elements at comparable $\mathrm{MgO}$ levels than basalts from either island. For example, at $10 \% \mathrm{MgO}$, Site 715 lavas contain $80,140,80$, and $25 \mathrm{ppm}$ of $\mathrm{Ba}, \mathrm{Sr}, \mathrm{Sr}$, and $\mathrm{Y}$, respectively. This compares with values for Réunion (and Mauritius) of about $180(250), 380(370), 200(180)$, and $30(30) \mathrm{ppm}$ (Baxter, 1972; Upton and Wadsworth, 1972). In this respect, Site 715 compositions more closely approximate the low levels of the Ambenali Formation (cf. Cox and Hawkesworth, 1985).

Incompatible-element ratios for the low and high $\mathrm{MgO}$ classes (Table 2) are very similar, emphasizing their genetic links. $\mathrm{Ba} /$ $\mathrm{TiO}_{2}$ ratios average 63, the highest of any Leg 115 site and close to Réunion values (about 70). This implies a source for Site 715 substantially enriched relative to that of MORB. $\mathrm{Zr} / \mathrm{Nb}$ ratios average 7.9, again close to that for Réunion Island (7.5). These characteristics indicate that Site 715 basalts were produced from an OIB (plume-type) source, although the substantially lower $\mathrm{Nb} / \mathrm{Y}$ values for the lavas (about 0.40 ) compared with Réunion
(0.87) implies significant compositional differences to that of the active hotspot.

\section{INTERSITE GEOCHEMICAL VARIATION}

A common feature in all of the preceding discussions of individual site characteristics is the evidence of a variable interplay of OIB- and MORB-like mantle sources in the magma generation process. These data, as well as the data for the other analyzed components of the hotspot trace (Deccan, Mauritius, and Réunion), allow these features to be assessed in the context of the magmatic evolution of the Deccan-Réunion lineament. Fisk et al. (1989) have demonstrated that the hotspot trace shows an overall progression in incompatible-element ratios, from MORBto OIB-type values. This temporal shift coincides with a systematic decrease in $\mathrm{Nd}$ isotopic ratios toward increasingly OIB-like values (White et al., 1988).

Figure 3 summarizes the incompatible-element ratio variations along the lineament. The $\mathrm{Ba} / \mathrm{TiO}_{2}$ ratios, generally regarded as indicative of source enrichment relative to MORB, rise from about 20 at Site $707(64 \mathrm{Ma})$ to 70 at Réunion $(0-2$ $\mathrm{Ma})$. $\mathrm{The} \mathrm{Nb} / \mathrm{Y}$ values rise over the same interval from 0.14 to 0.86 , whereas the $\mathrm{Zr} / \mathrm{Nb}$ values decline from 14 to 7.5 . $\mathrm{Nb}, \mathrm{Y}$, and $\mathrm{Zr}$ are all HFS elements; as such, they are fairly immobile, which makes them useful in assessing contributions from distinct mantle source compositions. The $\mathrm{Zr} / \mathrm{Nb}$ ratios can be of particular value in recognizing source heterogeneity, as these are thought to be insensitive to variations in the degree of partial melting (Pearce and Norry, 1979).

Although a broad trend toward OIB-like ratios with decreasing age is evident, some deviations from this occur. For example, Site 715 plots off the trend, with values implying a significant OIB component to its source. Furthermore, the similarities to MORB of the depleted lower-group lavas of Site 706, and of all Site 713 lavas, are particularly evident in the $\mathrm{Nb} / \mathrm{Y}$ plot and, to a lesser extent, in the $\mathrm{Ba} / \mathrm{TiO}_{2}$ plot. It is also clear that all of the products of the hotspot have melted from a source that is compositionally distinct in terms of $\mathrm{Zr} / \mathrm{Nb}$ from that of the CIR basalts.

The initiation of Réunion hotspot activity was marked by regional scale flood basalt eruptions in the Deccan. The estimated volume of this event $\left(1.5 \times 10^{6} \mathrm{~km}^{3}\right)$ matched that of all later products along the lineament. Mahoney et al. $(1982,1985)$ and Cox and Hawkesworth $(1984,1985)$ identified three formations within the Deccan sequence (Mahabaleshwar, Ambenali, and Poladpur) that reflect the varying dominance of plume, asthenosphere, and continental lithosphere sources, respectively, in this major melting event. This is reflected in the wide range of incompatible-element ratios for the Deccan lavas (see Fig. 3). The asthenospheric melts of the Ambenali Formation show generally similar ratios to Site 707 , whereas the plumelike affinities of the Mahabaleshwar Formation are reflected in its similarity to Site 715, Réunion, and Mauritius.

The observation that very large-scale melting characterized the start-up of the Réunion hotspot, whereas the latest activity has been marked by a transition from the formation of a continuous lineament to discrete volcanic islands, may be significant in interpreting the temporal trends of incompatible-element ratios. These features could collectively reflect the life cycle of a major thermal anomaly in the mantle, in which the degree of partial melting essentially controls magma chemistry.

In its initial, high-productivity phase, substantial volumes of asthenospheric mantle might be entrained within the ascending plume (cf. Griffiths, 1986), this effect declining with the waning of the thermal cycle. By allowing progressive interaction between these two end-member sources, as well as variations in 

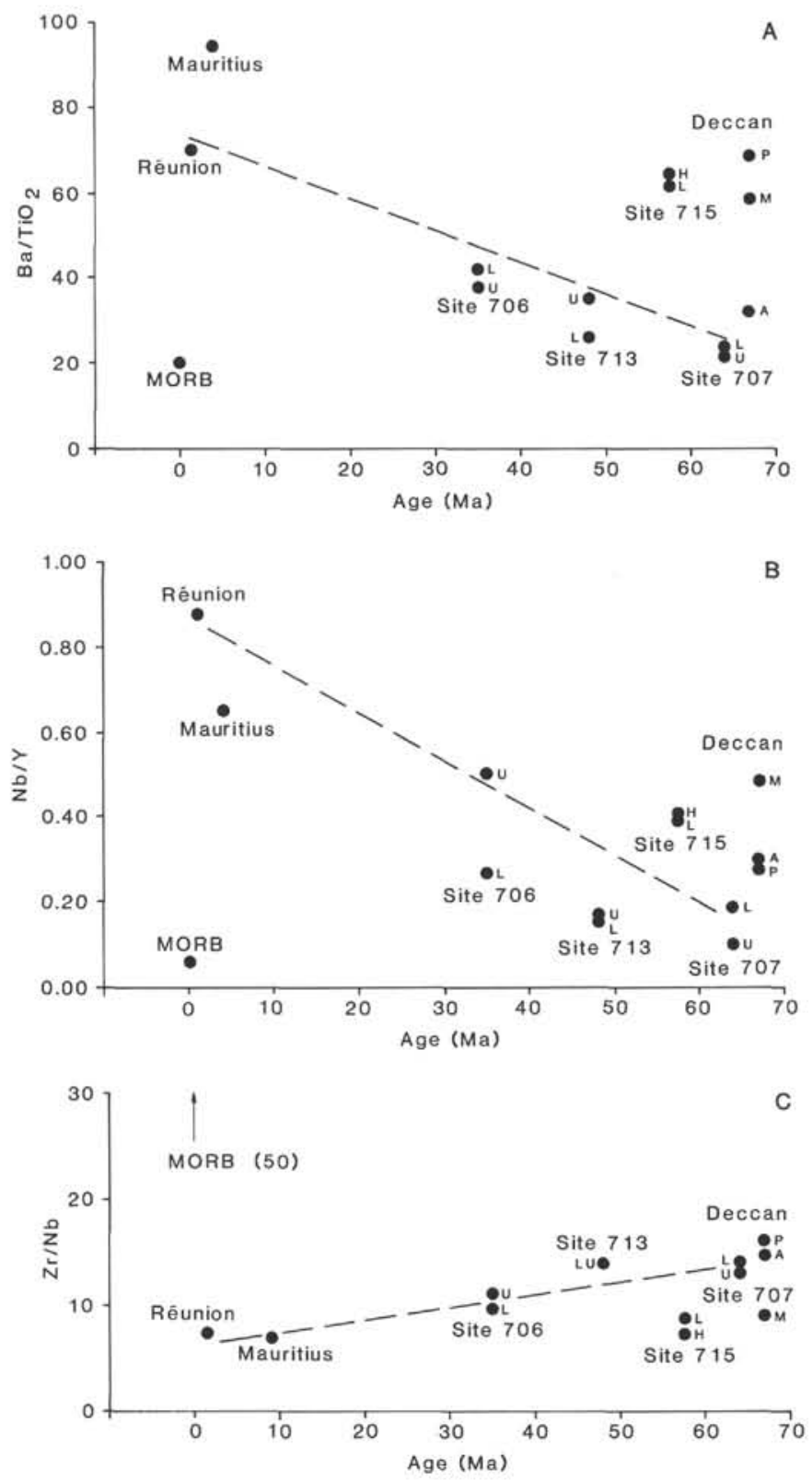

Figure 3. A. Mean $\mathrm{Ba} / \mathrm{TiO}_{2}$ ratios of basalts for components of the Deccan-Réunion lineament relative to age. The Deccan values are from Cox and Hawkesworth (1985), Mauritius from Baxter (1972), and Réunion from Upton and Wadsworth (1972) and Fisk et al. (1989). The MORB values are from the CIR (Mahoney et al., 1989). For Sites 706, 707 , and 713, $\mathrm{U}=$ upper-group lavas and $\mathrm{L}=$ lower-group lavas; for Site $715, \mathrm{~L}=$ low $\mathrm{MgO}$ class and $\mathrm{H}=$ high $\mathrm{MgO}$ class. $\mathrm{B}$. $\mathrm{Nb} / \mathrm{Y}$ ratios for basalts from the lineament. $\mathrm{C}$. $\mathrm{Zr} / \mathrm{Nb}$ ratios for basalts from the lineament.

the degree of partial melting, this model could account for the observed change in $\mathrm{Zr} / \mathrm{Nb}$ ratios, which appears to require more than one mantle source to be present. The Nd isotopic ratio variation along the hotspot trace is consistent with such a view (White et al., 1988).

Although this model could account for the chemical trends seen along the hotspot trail, it does not readily explain the evidence from Sites 706, 707, and 713 that melts from both MORBand OIB-like sources were often available simultaneously. Nor does it account for the plume-dominated characteristics of Site
715 at a time when asthenospheric influence should have been high. To reconcile this, it is necessary to assume that local factors were operating in the mantle under each site.

An alternative explanation for the regional trend may lie in the relationship between the tectonic setting of magmatism and magma chemistry. Depleted, MORB-like compositions are most abundant along the hotspot trace, where reconstructions place activity under or adjacent to active spreading ridges (e.g., Sites 706 and 713). This might imply that the primary control on the magma chemistry lies in the availability of asthenospheric mantle and/or melts for mixing with plume material. At the same time, the overall temporal change in incompatible-element ratios could reflect the generalized shift in hotspot setting from an asthenosphere-dominated melting regime (plate boundary) to a plume-dominated (within-plate) setting.

\section{SUMMARY}

Basalts recovered from the Leg 115 sites are all tholeiitic, with differentiation indexes varying from 16 to 31 and magnesium ratios from 31 to 64 .

Site 706 lavas can be subdivided chemically into two groups, both of which erupted in a submarine environment. The upper group comprises a mildly differentiated suite of porphyritic basalts with a phenocryst assemblage of plagioclase, subordinate augite, and minor olivine. Chemical variation in this unit is consistent with fractionation of these phases. Their chemical characteristics (high $\mathrm{TiO}_{2}$, total iron, and alkalis), coupled with elevated incompatible trace element levels, resemble those of oceanic-island basalts (e.g., Réunion). In contrast, the lowergroup lavas, although mineralogically similar, display a depleted incompatible-element chemistry, allied to high $\mathrm{Al}_{2} \mathrm{O}_{3}$ and $\mathrm{CaO}$, which resembles that of MORB lavas. The two groups cannot be related by fractionation processes and they represent two magma types, with different mantle sources.

At Site 707 a suite of subaerial, often thick, porphyritic basalt lava flows, erupted within the geographic province of the western Deccan Traps. Phenocryst assemblages consist of plagioclase with subordinate augite and minor olivine. As at Site 706, two distinct magma types were recognized. An upper lava group displays a depleted incompatible-element chemistry with levels 1-4 times less than that of the lower group. Enrichment in the lower group is associated with lower $\mathrm{MgO}, \mathrm{SiO}_{2}, \mathrm{Al}_{2} \mathrm{O}_{3}$, and higher total iron. Chemical variation in this group can be related in part to plagioclase-dominated fractionation.

Modeling and incompatible-element ratios show that the two groups cannot be genetically linked by fractionation and that compositional differences result, instead, from an interplay of asthenospheric and plume sources. Lower-group lavas, although showing some similarities to the Ambenali Formation of the Deccan Traps, have significantly lower incompatible-element abundances and lower $\mathrm{Ba} / \mathrm{TiO}_{2}$ and $\mathrm{Nb} / \mathrm{Y}$ ratios.

Site 713 lavas are submarine-erupted, microporphyritic-porphyritic basalts, with (micro)phenocryst assemblages dominated by plagioclase plus augite and minor olivine. Two contrasting magma types can be recognized, but with the distinction blurred in this case by the overprinting effects of high-level crystal fractionation. An upper group of slightly enriched basalts is similar to the lower-group lavas of Site 707, whereas a lower lava group of significantly more depleted lavas is intermediate in composition between the MORB-like basalt groups of Sites 706 and 707 .

As at Site 707, enrichment is associated with marginally lower $\mathrm{MgO}$ levels, but once again modeling and incompatible-element ratios preclude crystal fractionation as the dominant control. Variably mixed asthenosphere/plume sources appear to be implicated in the formation of the two groups.

Site 715 basalts form a differentiated suite of subaerially erupted lavas that include the most mafic, olivine-rich lavas re- 
covered on Leg 115. The relative dispersion of $\mathrm{Na}_{2} \mathrm{O}, \mathrm{K}_{2} \mathrm{O}$, and LIL elements evident in $\mathrm{MgO}$ plots reflects mobilization caused by laterization processes. Despite this, two compositional classes of basalt were recognized, one with high $\mathrm{MgO}, \mathrm{Ni}$, and $\mathrm{Cr}$, but depleted incompatible-element levels, and the other with low $\mathrm{MgO}, \mathrm{Ni}$, and $\mathrm{Cr}$, and high incompatible elements. Site 715 lavas show close chemical affinities to Mauritius and Réunion, and a dominantly plume-type source mantle is indicated for this volcanism.

Average incompatible-element ratios $\left(\mathrm{Ba} / \mathrm{TiO}_{2}, \mathrm{Nb} / \mathrm{Y}\right.$, and $\mathrm{Zr} / \mathrm{Nb}$ ) for the four sites, together with those for the Deccan formations, Mauritius, and Réunion, show evidence of a broad, linear change from MORB- to OIB-like values associated with the evolution of the hotspot.

That MORB-like values are most prevalent when the hotspot was under or adjacent to spreading ridges implies that a major control on magma chemistry may lie in the variable availability of asthenospheric mantle/melts for mixing with ascending plume material. The temporal shift to increasingly OIB-like compositions would then reflect the general translation of hotspot setting from asthenosphere-dominated (plate boundary) to plumedominated (within-plate) melting regimes, as the Indian Ocean lithosphere migrated over it.

Alternatively, the hotspot may represent an evolving thermal event. Very large-scale melting characterized the initiation of the hotspot (Deccan Traps), with recent activity marking a transition from the formation of a continuous volcanic lineament to discrete oceanic islands (Mauritius, Réunion). In such a thermal event, substantial entrainment of asthenospheric material within the ascending plume mantle might be expected early in the hotspot history, declining with time to produce the observed OIBdominated compositions. This effect alone, however, cannot generate the local compositional deviations from the general trend observed at some sites.

\section{REFERENCES}

Allégre, C. J., Treuil, M., Minster, J-F., Minster, B., and Albarede, F., 1977. Systematic use of trace elements in igneous processes. Contrib. Mineral. Petrol., 60:57-75.

Backman, J., Duncan, R. A., et al., 1988. Proc. ODP, Init. Repts., 115: College Station, TX (Ocean Drilling Program).

Baxter, A. N., 1972. Magmatic evolution of Mauritius, western Indian Ocean [Ph.D. thesis]. Edinburgh Univ., Scotland, U.K.

1975. Petrology of the older series lavas from Mauritius, Indian Ocean. Geol. Soc. Am. Bull., 86:1449-1458.

1976. Geochemistry and petrogenesis of primitive alkali basalt from Mauritius, Indian Ocean. Geol. Soc. Am. Bull., 87:10281034.

Clague, D. A., and Frey, F. A., 1982. Petrology and trace element geochemistry of the Honolulu volcanics, Oahu: implications for the oceanic mantle below Hawaii. J. Petrol., 23:447-504.

Cox, K. G., and Hawkesworth, C. J., 1984. Relative contribution of crust and mantle to floor basalt magmatism, Mahabaleshwar area, Deccan Traps. Phil. Trans. R. Soc. London, Ser. A, 301:627-641.

1985. Geochemical stratigraphy of the Deccan Traps at Ma habaleshwar, Western Ghats, India, with implications for open-system magmatic processes. J. Petrol., 26:355-377.
Duncan, R. A., and Pyle, D. G., 1988. Rapid eruption of the Deccan flood basalts at the Cretaceous/Tertiary boundary. Nature, 333:841843.

Fisk, M. R., Duncan, R. A., Baxter, A. N., Greenough, J. D., Hargraves, R. B., Tatsumi, Y., and Shipboard Scientific Party, 1989. Reunion hotspot magma chemistry over the past $65 \mathrm{~m} . \mathrm{y}$.: results from Leg 115 of the Ocean Drilling Program. Geology, 17:934-937.

Fisk, M. R., Upton, B.G.J., Ford, C. E., and White, W. M., 1988. Geochemical and experimental study of the genesis of magmas of Réunion Island, Indian Ocean. J. Geophys. Res., 93:4933-4950.

Griffiths, R. W., 1986. The differing effects of compositional and thermal buoyancies on the evolution of mantle diapirs. Phys. Earth Planet. Inter., 43:261-273.

Humler, E., and Whitechurch, H., 1988. Petrology of basalts from the Central Indian Ridge $\left(25^{\circ} 23^{\prime} \mathrm{S}, 70^{\circ} 04^{\prime} \mathrm{E}\right)$ : estimates of frequencies and fractional volumes of magma injections in a two-layered reservoir. Earth Planet. Sci. Lett., 88:169-181.

McDougall, I., 1971. The geochronology and evolution of the young volcanic island of Réunion, Indian Ocean. Geochem. Cosmochim. Acta, 35:261-270.

McDougall, I., and Chamalaun, F. H., 1969. Isotopic dating and geomagnetic polarity studies on volcanic rocks from Mauritius, Indian Ocean. Geol. Soc. Am. Bull., 80:1419-1442.

Mahoney, J. J., 1988. Deccan Traps. In McDougall, J. D. (Ed.), Continental Flood Basalts: Dordrecht, The Netherlands (Kluwer Academic Publishers), 151-194.

Mahoney, J. J., Macdougall, J. D., Lugmair, G. W., Gopalan, K., and Krishnamurthy, P., 1985. Origin of contemporaneous tholeitic and K-rich alkalic lavas: a case study from the northern Deccan Plateau, India. Earth Planet. Sci. Lett., 72:39-53.

Mahoney, J. J., Macdougall, J. D., Lugmair, G. W., Murali, A. V., Sankar Das, M., and Gopalan, K., 1982. Origin of the Deccan Trap flows at Mahabaleshwar inferred from $\mathrm{Nd}$ and $\mathrm{Sr}$ isotopic and chemical evidence. Earth Planet. Sci. Lett., 60:47-60.

Mahoney, J. J., Natland, J. H., White, W. M., Poreda, R., Bloomer, S. H., Fisher, R. L., and Baxter, A. N., 1989. Isotopic and geochemical provinces of the western Indian Ocean spreading centers. J. Geophys. Res., 94:4033-4052.

Meyerhoff, A. A., and Kamen-Kaye, M., 1981. Petroleum prospects of the Saya de Malha and Nazareth Banks, Indian Ocean. AAPG Bull., 65:1344-1347.

Pearce, J. A., and Norry, M. J., 1979. Petrogenetic implications of Ti, $\mathrm{Zr}$, $\mathrm{Y}$ and $\mathrm{Nb}$ variations in volcanic rocks. Contrib. Mineral. Petrol., 69:33-47.

Schlich, R., 1982. The Indian Ocean: aseismic ridges, spreading centers and oceanic ridges. In Nairn, A.E.M., and Stehli, F. G. (Eds.), The Ocean Basins and Margins (Vol. 6): New York (Plenum Press), 51147.

Upton, B.G.J., and Wadsworth, W. J., 1972. Aspects of magmatic evolution of Réunion Island. Phil. Trans. R. Soc. London, Ser. A, 271: 105-130.

White, W. M., Backman, J., Duncan, R. A., et al., 1988. Réunion to Deccan: history of a hotspot from ODP Leg 115 drilling. Eos, 69: 476-477.

Wood, D. A., Joron, J. L., Treuil, M., Norry, M. J., and Tarney, J., 1979. Elemental and $\mathrm{Sr}$ isotope variations in basic lavas from Iceland and the surrounding ocean floor. Contrib. Mineral. Petrol., 70: 319-339.

Date of initial receipt: 11 July 1989

Date of acceptance: 8 January 1990

Ms 115B-133 